\title{
PR 2.0 and Interaction of Turkish Brands in Terms of Brand Awareness
}

\author{
PR 2.0 ve Marka Bilinirliğinin Türk Markaları Açısından Etkileşimi
}

\author{
Ece BABAN
}

Assistant Professor,, Okan University, Turkiye, ece.baban@okan.edu.tr

\begin{abstract}
Today, under the affect of market conditions, companies prefer social media channel with the aim of reaching their target population, interacting with their customers directly and expressing their brands more powerfully in the market. Companies are trying to perform new strategies for creating close relationships between brand and customers, while the differentiation attempts of the companies. Nowadays, the Internet phenomenon is one of the most important factors in this regard. People spend most of their times at the computer and internet networks. In the 1990s, with the spread of internet and mobile phones, public relations activities moved to electronic and digital media of mass communication as a one-way by using e-mail, SMS and fax machine tools. In the 2000s, by the development in web area, with the help of 2.0 patches, people can also edit the pages instead of just reading the written pages through the web pages. In today's competitive environment and the developments that followed the progress of technology companies and companies with a progressive web influenced by these developments and the opportunities created by social media, they introduce their products and services and increase customer satisfaction for better uses. PR activities which use Web 2.0 and technological developments in social media environment are called PR 2.0. Throughout the research, PR 2.0 activities within the scope of the contribution of brand awareness through social media, especially in comparison with traditional $P R$ will be discussed. Brands will be examined regarding the brands which are actively using the social media in terms of the public relations and brand awareness. Brands can be listed in four different business sectors such as; Mavi Jeans, Anadolu Efes Pilsen, Garanti Bankası and ETI.
\end{abstract}

Keywords : : Brand Recognition, PR 2.0, Social Media, Web 2.0. 
ÖZET Günümüzde pazar koşullarında firmalar, hedef kitlelerine ulaşabilmek, sahip olduklarn markaları yoğun rekabet koşulları altında ön plana çıkartabilmek, tüketici ile doğrudan buluşturabilmek amacıyla çoklu medya kullanımlarına yönelmektedirler. Firmaların tüketicileri çepeçeore sarmaya çabaladikları bu süreçte, farklılık yaratmak, benzersiz ya da alternatif yaklaşımlarla marka ve tüketiciyi birbirine yakınlaştırma temeline dayanan stratejiler geliştirilmektedir. Günümüzde internet fenomeni bu anlamda en önemli etkenlerden birisidir. Artık insanlar yaşamlarının büyük bir kısmını bilgisayar başında ve internet ağlarında geçirmektedir. 1990'lı yıllarda internet ve cep telefonlarının yaygınlaşması ile halkla ilişkiler faaliyetleri de elektronik ve dijital ortama taşınmış ve kitle ile iletişim e-mail, kısa mesaj(SMS) ve fax gibi araçlar ile tek yönlü olarak yapılmaya başlanmıştır (Jalali, 2009). 2000'li yillarda, web'in gelişmesi, web kavramma 2.0 ekinin eklenmesine sebep olmuş; web sayfaları sadece okunabilir sayfalar şeklinden çıkmış, web sayfaların okuyan kişiler, o sayfalarda yazma imkanı bile bulmuşlardır. Bugünkü rekabet ortamında ise teknolojinin ilerlemesini takip eden ve bu gelişmeler ile ilerleyen firmalar ve şirketleri web'i bu gelişmelerin ve sosyal medyanın oluşturduğu olanaklardan etkilenerek, onları kendi ürün ve hizmetlerini daha iyi tanıtmak ve müşteri memnuniyetini artırmak için kullanmaktadır. Sosyal medya ortaminda, Web2.0 ve teknolojik ilerlemelerden yararlanarak yapılan halkla ilişkiler faaliyetlerine halkla ilişkiler 2.0 adı verilmektedir (Jalali, 2009).Çalışma kapsamında halkla ilişkiler 2.0 çalışmalarının marka bilinirliğine katkısı sosyal medya üzerinden özellikle geleneksel halkla ilişkiler ile karşılaştırılarak ele alnnacaktır. Marka olarak Türkiye'de sosyal medyayı en aktif kullanan farklı sektörlerden markalar ele alınarak halkla ilişkiler ve marka bilinirliği açısından incelenecektir. Markalar Mavi Jeans, Anadolu Efes Pilsen, Garanti Bankası ve ETİ olarak dört farklı sektörden belirlenmiştir.

Anahtar Kelimeler: Marka Bilinirliği, PR 2.0, Sosyal Medya, Web 2.0. 


\section{INTRODUCTION}

Persuasion has been defined in many different ways over the centuries. The formal study of persuasion traces its roots to the Ancient Greeks, who were the first to systematize the use of persuasion. They called it Rhetoric. Aristotle says 'rhetoric is the power to see, in each case, the possible ways to persuade. According to him a skilled rhetorician can gain credibility and moves his audience towards the desired end (Shilds, 2007). In the rhetoric Aristotle distinguishes three means of persuasion. The word pistis, although translated 'proof'. Its use encompasses the related qualities of trust, trustworthiness, credence and credibility, and extends to objects and means used to secure thrust or belief. Whereas, "pathos" is defined by Aristotle as a "creating a certain disposition in the audience". Ethos, a moral character as means of persuasion consists in creating through the speech character that will induce the required degree of trust on the part of the hearer. Aristotle also thought that the persuasion is most effective when based on the common ground existing between persuader and persuade (Carey, 1996). The other important term in Aristotle's philosophy is logos. A logo might be sentence or a statement, or appropriately connected set of statements, an argument (Shilds, 2007). Aristotle made a major focus on the source credibility. And he implies the importance of openness, simplicity. Wisdom also plays a substantial role in his rhetoric. According to him, wisdom can be conveyed by using generalizations. By laying claim to certain beliefs that agree with accepted social values a speaker can empathize with the audience (Carey, 1996). There is an element of persuasion on the basis of public relations. PR is the art of persuasion. Therefore the relationship between public relations and social media will be evaluated in this respect. The key terms of persuasion are very important as public relations. They are; belief, value, attitude, behavior. These concepts are very important in terms of public relations. They are necessary for public relations. While examining the relationship between persuasion tools and public relations we should understand the mass media and social media channels. Especially, research will examine the brand's persuasion effect on customers with today's technological environment including social media and mass media and digital media also will be discussed.

\section{MASS MEDIA - DIGITAL MEDIA}

Generally, mass media; Mass channels are impersonal channels and they have mechanical means to meet with the receiver. In this process mass communication is the process of creating shared meaning between the mass media and their audiences. Schramm recast his and Osgood's general mood of communication to help us visualize the particular aspects of the mass communication process. In the several decades of media studies below principles are adopted. Propaganda is thought to be highly effective and people cannot resist mass advertising. Propaganda may appear to be informative communication when ideas are shared, something is explained, or instructions take place. Thus, the propagandist will attempt to control information flow and manage a certain public's opinion by sharing perceptions through strategies of informative communication (Jowett \& O'donnell, 1999: 41). Blumler \& Katz (1974) argued that audience needs have social and psychological origins which generate certain expectations about the mass media, leading to differential patterns of media exposure which result in both the gratification of needs and in other consequences. This is called uses and gratification theory (Benjamin, 1997). Especially this theory applies for 
the social media. This theory focuses on why people use particular media rather than on content. In contrast to the concern of the 'media effects' tradition with 'what media do to people' (which assumes a homogeneous mass audience and a 'hypodermic' view of media), Uses and gratification theory can be seen as part of a broader trend amongst media researchers which is more concerned with 'what people do with media', allowing for a variety of responses and interpretation (Blumler \& Katz, 1974). They consume contents for fulfilling their information, entertainment, and mood management needs; they participate through interacting with the content as well as with other users for enhancing social connections and virtual communities; and they produce their own contents for selfexpression and self actualization. These three usages are separate analytically but interdependent in reality. This paper proposes a model to describe such interdependence. Furthermore, it argues that two usability attributes of UGM, "easy to use" and "let users control," enable people to perform the aforementioned activities efficiently so that people can derive greater gratification from their UGM use (Shao, 2009). News media sets the agenda. According to the agenda setting theory developed by Prof. Maxwell Macomb and Prof. Donald Shawn mass media sets the agenda for public opinion by focusing on certain news items. The media are instrumental in the diffusion of innovation. New ideas, new products, new services are brought to attention. Media appear to use a 'two-step flow' of communication. While it may seem that media have a direct influence on the receiver, the two-step flow theory suggest that media influence opinion leaders, and they use more personal channels to reach receivers. Media have a selected and limited impact on receivers. Rather than changing the opinion, it influences or reinforces an opinion. People use media as models. The way the behavior appears on the media shapes the audience. Media establish social expectations. Media is accepted as one of the sources we learn the expected rules and norms of social behavior. The media define reality. The representations of the media provide definitions of reality that receivers later apply when similar events occur in their lives. More intense use of media cultivates more intense views of reality (Benjamin, 1997).

Digital Media: Digital content, whether multimedia or not, allows information designers to create "information or entertainment experiences that can be exactly tailored to individual needs and can be accessed when the user wants those experiences. In this situation, the substance of the content experience is determined more by the user than the supplier. This leads to a massive shift in the balance of power between the two (Thompson, 1997). This does not only change the balance of the broadcaster and the audience. This also reflected upon the other mass medium channels. The term of media meshing gain a significant importance. Media meshing is defined as the process of using one of the media such as blog or a website, to enhance the experience of another medium, such as a newspaper article or a financial television program with the diversity of online services the accessibility and prevalence of simultaneous media experiences have come to point which is full of more demanding and more inquisitive information consumer. As media becomes digital, advertising will become digital. In the future, digital advertising will be infused everywhere. Yet the goal has remained the same: connect with audiences. Media Buyers, in turn, have made an investment on the digital media. Technology has changed drastically. But the way it has been picked up by the younger generation has been even more amazing. The speed of adaptation in the young segment has never been seen before in any other medium that has been launched before the new web consumer is young $16-25$ s. According to a research in 
partnership with MTV and Microsoft which ran in UK, Italy, Netherlands, Germany, Mexico, China, India and Japan, 240 young people between the ages of 10 and 20 years old. (Breakenridge, 2009: 13)

\section{SOCIAL MEDIA AND WEB 2.0}

Social media simply is an environment which enables communication between people by using the internet (Breakenridge, 2009:15). This new media allows people to publish their ideas, experiences and knowledge in a global environment. In many cases, the voice of a normal person in this environment becomes as loud as that of famous journalists and experts. Social media eliminates distances, allows feedback, facilitates information sharing, provides effective communication and creates an online culture. In this way, all social media users become content creators. Blogs, social networks, microblogs, social bookmarking, podcasts, wikis and forums are known as the main styles of social media (Myfielde, 2008:526).

A user generated content, personalized media, open platforms and global social networks. Beyond profiles, Friends, comments, and private messaging, SNSs vary greatly in their features and user base. Some have photo-sharing or video-sharing capabilities; others have built-in blogging and instant messaging technology. There are mobile-specific SNSs (e.g., Dodgeball), but some web-based SNSs also support limited mobile interactions (D. M. Doyd \& Ellison, 2007). Social network sites are web-based services that allow individuals to construct a public or semi-public profile within a bounded system, articulate a list of other users with whom they share a connection, and view and traverse their list of connections and those made by others within the system. The nature and nomenclature of these connections may vary from site to site. What makes social network sites unique is not that they allow individuals to meet strangers, but rather that they enable users to articulate and make visible their social networks. This can result in connections between individuals that would not otherwise be made, but that is often not the goal, and these meetings are frequently between "latent ties" who share some offline connection. On many of the large social media platforms, participants are not necessarily "networking" or looking to meet new people; instead, they are primarily communicating with people who are already a part of their extended social network (Doyd \& Ellison, 2007). Social Media and Web 2.0 concepts are very similar in the opportunities and functions they provide. (Solis, 2009:34) Web 2.0 is a concept that describes the evolution of internet and web. This concept has emerged following the changes in the usage of web and internet, and their interactive use. After the introduction of Web 2.0, many internet users have begun writing web blogs (Emami, 2009:94). Web 2.0 develops new ways for the users to collect and share information (Oftade, 2009:124). By means of Web 2.0, consumer user has changed into information creating user (Jalali, 2009:183). In other words, web 2.0 may be described as the interaction of human being with the internet.

\section{PR 2.0}

PR (Public Relations) can be defined as a method for creating a public which are the member of a democratic society and gaining trust, approval and respect (Biber, 2009). 
According to Castells, individuals are now living in a network society that they are connected locally and globally. Network is emerged with the help of internet which is always on or accessible and changed the concept of "place", sense of distance (Varnelis, 2008: 26). Internet changed everything for the sense of public relations. Companies are not just publishing the important and useful information, but also they provide continuous two way communication between company and their target (Breakenridge, 2008: 14). According to four ring model by Grunig and Hunt; the communication environment through internet is two way, unstable and asymmetric before social media. Social media emerged as a two way symmetric communication environment that provides balanced interactive communication between target groups and companies without time and location constraints. Networks, which are emerged spontaneously without time and location constraints, have become an effective, efficient and measurable communication channel of PR for public opinion, trust, approval, consent, and respect construction. The world we live in changes quickly by means of the internet, other technological developments and globalization processes. These changes occur in commercial, political, cultural and social areas. Internet and technological innovations that are significant for PR are essential for the companies since they produce important results about sharing and distributing information for the concerned public. Since most of the operations are realized by using the internet environment, majority of the public relation groups are on the internet and increasing number of people is getting accustomed to advantages of the speed of this virtual environment and its global manner, PR experts have been pushed to realize their activities on the internet and create PR 2.0 concept together with public relations. People tag each other on the internet, discuss there and unconsciously make public relations activities in social media environments. Therefore, this area becomes an important environment for the firms. Since the capital, products and brands have exceeded the borders and have had new meanings there, the use of new contemporary technologies in PR sector has become necessary. "People tag each other on the internet, discuss there and unconsciously make public relations activities in social media environments. Therefore, this area becomes an important environment for the firms and brands by means of the activities of the people in social media." (Guz and Zafarmand, 2009:2). With PR 2.0 process, it is possible to reach people not only indirectly but also directly. "For example, in Facebook group that is created for a movie, people can exchange their views about the film. This is a PR activity for the movie and bears advantages for the publicity of the movie. By means of PR 2.0, it is also possible to contact directly to journalists and customers. In societies where PR 2.0 is used, there are public relations departments that work 7 days for 24 hours. They are always in contact with their target group.

\subsection{The features of PR 2.0}

"PR 2.0, different from traditional PR applications with its elements like speed, costeffectiveness, freedom, mobility, target-orientedness, proactivity, borderlessness, creativity, mutual contact ability, high quality database, measurements, immediate contact ability and imagination (Marsden, 2008; Sherman, 2008; Erman, 2009), prepares new opportunities in PR area. Because of its ability to reach target groups directly and its ability to allow the users shape the content, PR 2.0 facilitates reaching the goal. In the globalized world, PR 2.0 fulfills its social, cultural and situational roles and shapes the development of information totality 
that will be shared and exchanged after the introduction of the appropriate equipment. PR 2.0 makes better analysis of the customers and managed groups who live in their digital, electronic and cyber world, and enables the introduction of more clear solutions.

\subsection{The use of PR 2.0}

PR 2.0 encourages the communication that is made for searching, producing and sharing the information in collaboration. Cost-effectiveness, speed and accessibility are the most important features and advantages of PR 2.0. PR 2.0 has changed the traditional ways of meeting a customer. The changes coming with virtual environment technologies like Twitter, Facebook, YouTube etc. has accelerated public relations activities and services and facilitated the use of these activities and services, and are open to use by everyone. Facebook and Twitter are most popular social media tools in Turkey (Alexa, The Web Information Company,2012). User number of Facebook is 509.422.080 while there are 23.516.140 users in Turkey (Socialbarkers,Social Strategy Blogs, 2012). Facebook, social networking site, is second most clicked web site in Turkey (Ipsos KMG, 2009). Facebook users usually have a tendency to give respond quickly to any circumstances that are related to real-life situation (Toprak et al., 2009: 46). Members of these groups in Facebook are organizing campaigns on various issues (Toprak et al, 2009:47). According to data in 2010 July, user number of Twitter is 93 million while there are 7 million users in Turkey (Comscore, Analytics For The Digital World,2012). Organizations can deliver instant messages with Twitter, also by mobile devices. There is no healthy enough data about YouTube because government banned the access to YouTube in Turkey for a long time. Companies and institutions can easily contact with consumers by means of public relations. PR 2.0 is a lively environment with its own group and conversation power. These conversations (direct conversations with customers) create more meaningful participation and brand visibility, and help people decide. These conversations also encourage fidelity to the brand. Online conversations, content creation and sharing are characterized as the founding reasons of Web 2.0, social media and new public relations.

\section{SOCIAL NETWORKS AND PR}

Brogan puts it that the purpose of social media is to empower and enable conversations digitally: social media tools do a great job of capturing unstructured information, and can act perfectly as a crossover tool. Turner and Shah contend that social media can be an extremely effective sales tool for business-to-business companies. Social media is more fluid than traditional marketing, implies some form of digital social media or communications enabled through online technology, and has become overhyped. Most businesses use social media for one-way monologues. (Lazaroiu, 2010). Turner and Shah maintain that the secret to a successful social media campaign is to create circular momentum across many platforms. Doing the hard-sell using social media is usually counterproductive. Social media makes peers more immediately and dynamically available and can be segmented to reflect what consumer response it can best achieve. Social media's newness does not preempt the traditional rules of marketing. Embarking on a social media campaign is time consuming. (Turner and Shah, 2010) 
Social networks are defined as the contact points of web process and networks of online persons. Every active person has a profile and page in these networks. These people create content in their pages, manage and share them. By means of social networks, people can meet thousands of new people and contact them, and they can introduce themselves and even find sponsors. People who work together or firms whose works complete each other can create social networks composed of their own customers and groups, so that they can develop their activity environments and transform these interactions into customer fidelity.

All the duties of public relations departments can be fulfilled in social network environment. Chat facilities in these social networks make it possible to talk to the customer mutually. Latest news and developments about the firm, products and services can be declared in social networks. Promotions and campaign can be made easily in these environments. The favorite photos and videos of the firm can be presented in social networks and when these videos and photos are shared by the customers, people who are not customers of the company can see them and may be customers of the company. When users, firms, institutions and companies become member of the groups created by the social networks, the members can benefit from special services and campaigns particular to that environment and learn about the latest news. PR 2.0, by means of the analysis of PR 2.0, enables companies to identify the inclinations of the people and the firms they are associated with, and to know other companies that have the same goals as them. The organizations can contact with their interest groups mutually and interactively by using the facilities and tools of the social network environments, and by this way companies can realize their public relations networks. Content sharing websites: They enable users to share their videos, photographs and news in the virtual environment without any limit. Users can vote for these contents and comment on them. These operations that are made by printed newsletters, interviews or seminars, are made more quickly and cheaper when they are done with Web 2.0. Blogs: They are informing tools within companies or outside companies. In companies where PR 2.0 is used, nearly all the executives in big companies publish in their own blogs news and developments about their companies. In PR 2.0 activities, blogs are helpful for conveying the news about the firm or brand, introducing the skills, experiences and expertise of the firm, creating a leadership idea about the firm, finding supporters, contacting with the shareholders of the firm, creating a good and effective image of the firm by written texts and directing possible crisis in the firm.

Podcast: "They can be used as a publicity tool for the firms in PR 2.0. By means of this tool, companies can advertise even in multimedia format.

RSS: PR 2.0 expert can access all the information and content simultaneously and in the same environment. Microblogs: Microblogging tools helps firms follow on-air the events in areas that they are interested in and manage crisis, and they present news, announcements and notifications about firm and contribute to operations of public relations activities. In PR 2.0, Microblogs like Twitter are powerful tools both for employees and for customers. Wikis and forums are also used. Strategically, the most important things that PR 2.0 experts should do are to engage to their groups, carry their firm's or company's public relations activities to social media environments and contact with their interest groups by using social media tools and monitor what people speak or write about the firm. 
Anadolu Efes; There is a lot of information related to the team, the activities of the team and its social responsibility works in the Facebook page of Efes Pilsen. While especially ball bank application gives the target audience the feeling to play basketball from their computers as a game and to get involved in the fame, it is also known that the number of balls gathered in the ball bank is sent to train new basketball players. In the same way the player of the match application also enables the supporters to select the player of the match. With selections, videos and fan card applications, Anadolu Efes basketball team supports all of its promotion and social responsibility applications through social media. Mavi Jeans; Mavi Jeans implements some of its applications with the cooperation of its twitter micro blog through Facebook among the social networks. The application "Ask to Adriana Lima and let her answer for you" offers an event through internet for her followers though it is not possible to be realized through telephone or face to face and attracts both the followers of the brand and fans of Adriana Lima with a less cost. Moreover thanks to its cooperation with instagram application, St. Valentine's day, combine kisses and Mavi tweet wall applications organizes more creative activities for its followers and customers into which involves its customers together with extra campaigns. Garanti Bank; Garanti Bank can also announce its creative campaigns to its target audience by actively using social media. There are numerous applications and campaigns to promote internet banking in social media such as positive days application, iPhone $4 \mathrm{~s}$ campaign to increase the rate of using internet banking, giving Zynga play cars to one of every 100 person liking the page, trying to promote or increase the usage rate of Garanti Paramatik through Madonna concert and St. Valentine's day campaign. Eti; Eti actively uses social media as a support to its corporate promotional and social responsibility activities. Social responsibility projects are realized with the happiness volunteers society formed as a part of Eti's 50th anniversary events. Also Eti products are given away as presents with "Do you know which Eti?" application. Moreover promotion of children's theatre was made with Puss in Boots application. While Eti informs its customers about itself, it also creates sharing platforms by asking questions in different topics where they can express themselves about their social lives to have a personal contact with the consumer.

\section{CONCLUSION}

Big and small enterprises have a bilateral communication with their target audience by their presence in the internet environment not to fall behind one of the most active mass communication tools, internet and not to lose their audience. Thus they can maintain their position among their competitors and their popularity among their audience. As seen in the sample surveys, differently from conventional public relations, PR 2.0 gives the meaning of such factors as speed, low cost, innovation, freedom, purpose oriented approach, creativity, dynamism, easiness, participation, sharing, availability, computation, bilateralism, qualified data base, communication not oriented by media, limitlessness, clarity, viral distribution, contribution in creating content, differences, pro-activity and awareness. Moreover PR 2.0 differs from conventional PR with its features creating strategic communication of organizations and enterprises with correct computation aiming at the correct target audience, at the correct time, with the correct and creative tools, with correct and creative messages; and contributing to the qualified data base which also includes the target audience. Focusing on new technologies by using Web 2.0 tools with a purpose oriented 
approach and in an effective way, PR 2.0 intervenes the PR field to create new opportunities with effect oriented strategic communication approach. Beyond being a typical PR broadcasting mechanism, PR 2.0 is a lively organization with the power to talk to its own audience. These interactions (talking to the customers directly) help people decide by creating a more meaningful participation and brand recognition. These interactions also promote being bound to the brands. Online interactions, creating and sharing contents are seen as the foundation reasons of Web 2.0, social media and new public relations. With the development and more common usage of social networks and social media in following years, PR 2.0 activities will become more widespread and will witness the increase of the number of PR 2.0 companies. Especially the development of web 3.0 will contribute to the company and target audience perception of public relations and addition of a new model to public relations models as a communication discipline.

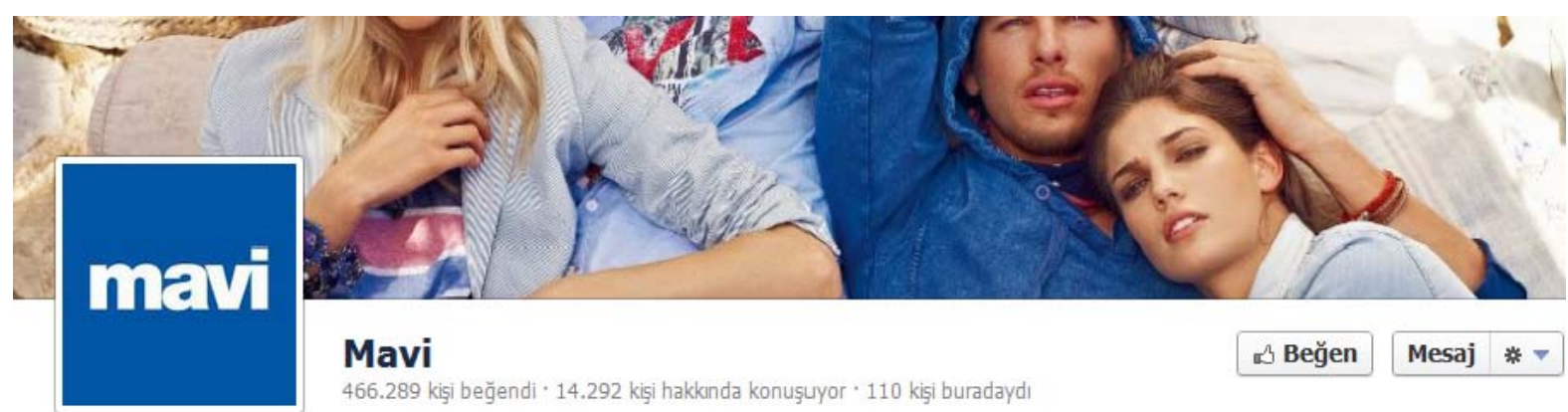

Giyim

Adriana Lima $\vee$ Mavi

Hakkanda

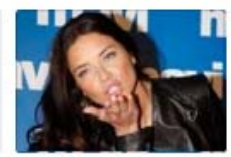

[屋 Fotoğraflar

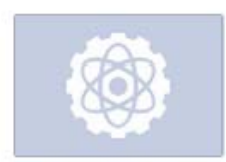

III Sevgilier Günü

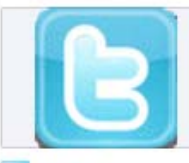

Twitter

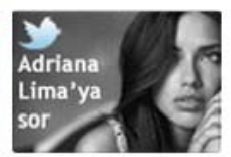

m Adriana Lima 'ya

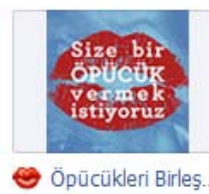

m

m Mavi'ni Bul

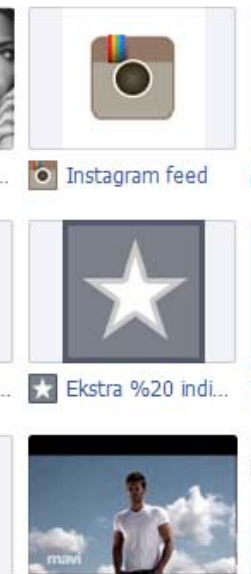

Hilleolar
$466 b$

[3] Beğenenler

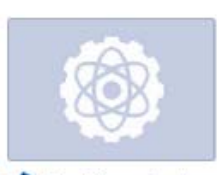

Kâgıthane :

- Istanbu

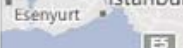

Q. Harita 


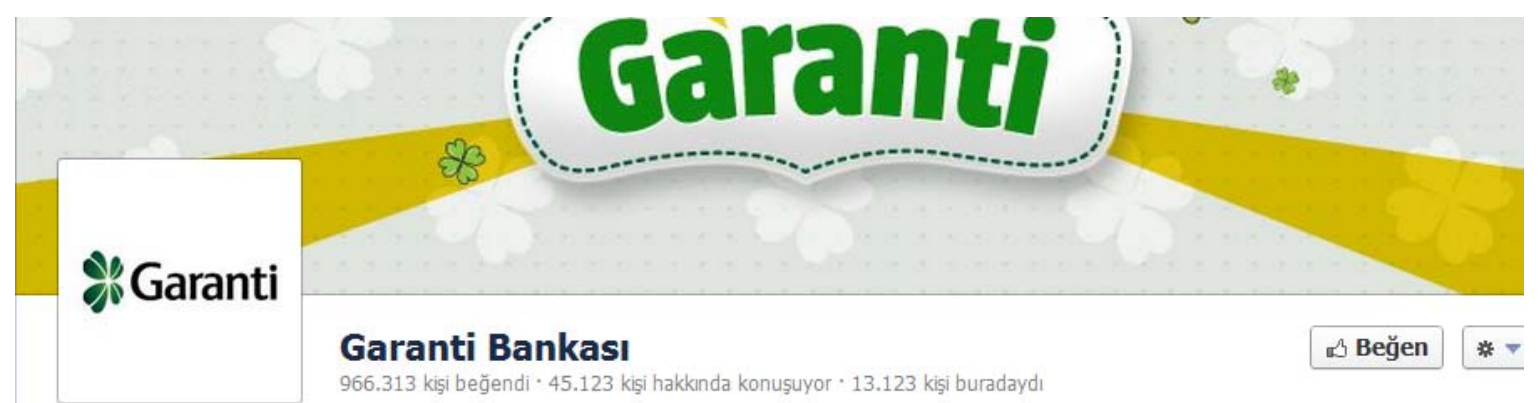

Banka/Finansal Kurulus

Garanti Bankası resmi Facebook sayfasına hoşgeldiniz!

Garanti hakkindaki tüm haberleri, kampanyaları ve yenilikleri

sayfamıdan takip edebilirsiniz. www.garanti.com.tr

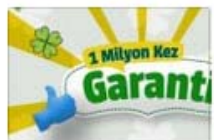

四 Fotoğraflar

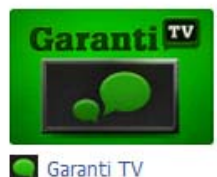

Q Garanti TV

Hafta Sonu Garan Bu Hafta!

Hafta Sonu Garanti'

hafta, NTV Yayinlar!

$\square$ Notlar

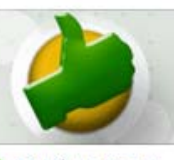

bir Milyon Kez G.

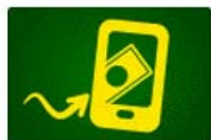

回 CepBank Para G... IIt] 25 iphone 45

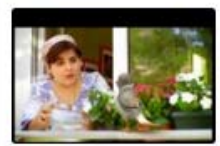

배 Videolar

(3) Beğenenler

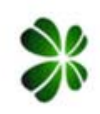

\& Garant

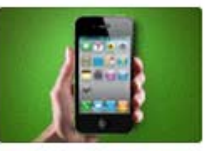

Tothane.

- Irom istanbul

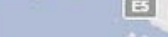

Q. Harita

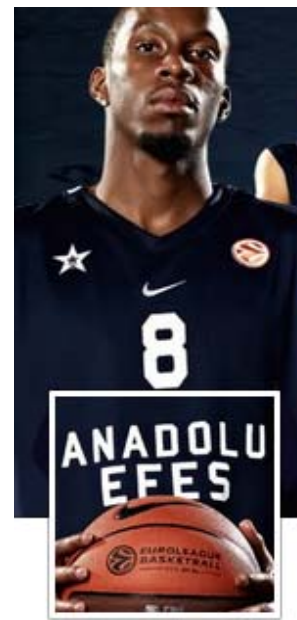

Profesyonel Spor Kulübi

Kurulduğ 1975 yundan bu vana Türk basketbol tarihinde Önemli zaferlere imza atmon Anadolu Efes Spor Kulübü'nün resmi Facebook hayran sayfasina hogggeldinizt

Hakkinda

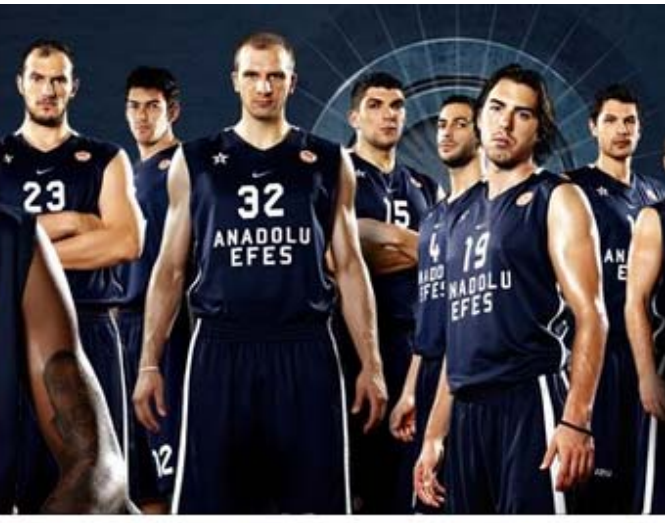

Anadolu Efes Spor Kulübü 68.893 kisi beğendi · 3.006 kiṣi hakkinda konușuyc

\section{ANADOLU EEES}

[1. Fotoğraflar

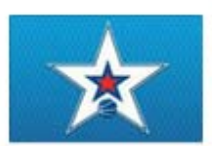

Anadolu Efes 5 .

\section{EFES BASKET TV}

Efes Basket TV

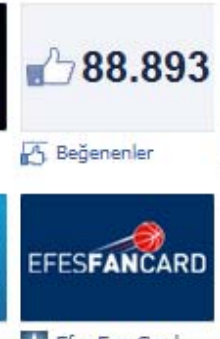

Ext Efes Fan Card

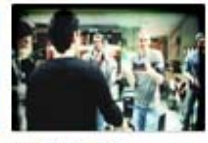

E Videolar

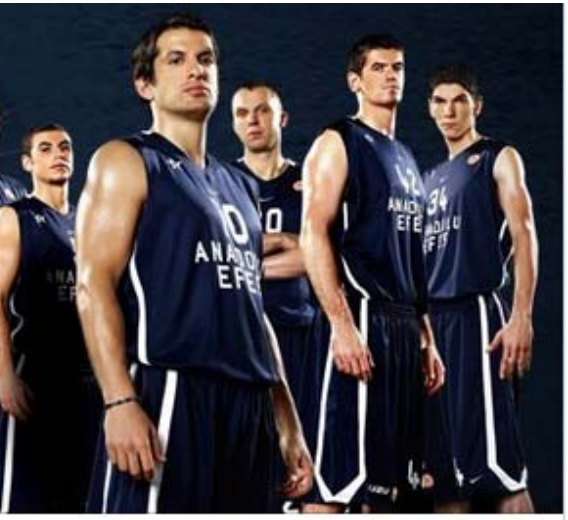

$\checkmark$ Beğendin Mesaj $*-$

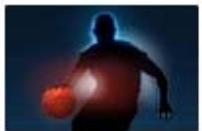

圆 Maçin Oyuncusu

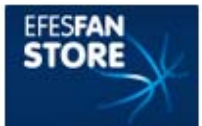

Efes Fan Store

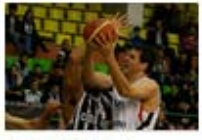

国 Etkinlikler
Etd Efes ile ilk Adim

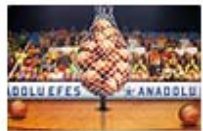

et Top Kumbaras!
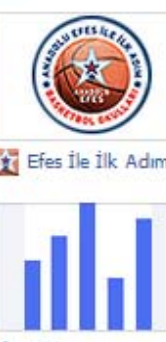


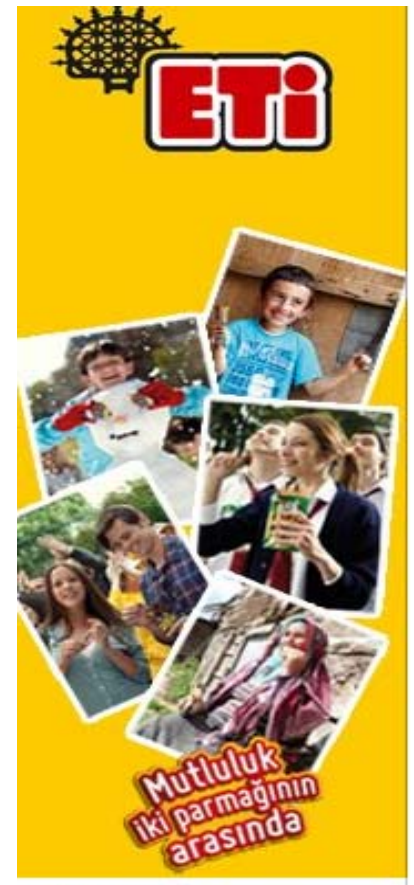

\section{Duvar}

国 Bilgiler

\&3 Arkadaşların Yaptkları (1+)

[目] Fotoğraflar

賏 Videolar

En Mutluluk Gönüllüleri

? Bil Bakalim Hanai Eti
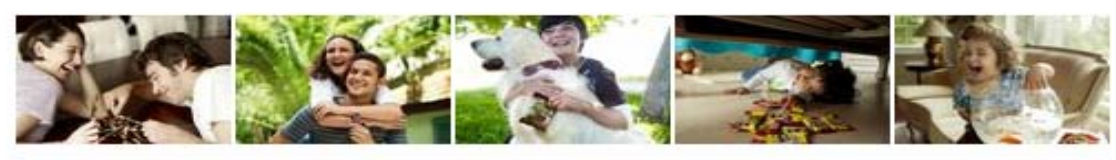

ETI · Herkes (En Yeniler)

Duvar

Paylaş: Gönderi

Bir şeyler yaz...

ETI

Kavrulmuş susamla kaplı, kıtır kıtır ETI Susamlı Çubuk'un susamlarını, paketi kafasına dikerek yiyenler 'beğen'sin :)

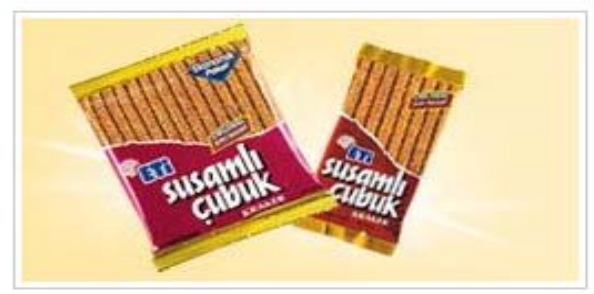

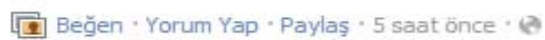

[3 337 kişi bunu beğendi.

무 28 yorumun tümünü gồ

T.2. Nazan Köseoğlu Burçakbaş 39 YAŞINA GELdì HALA YAPIYORUM

4 saat once - Beğen * 11

Yorum yaz.. 


\section{REFERENCES}

Benjamin, J. (1997). "Principles; Elements and Types of Persuasion”. United States of America: Harcourt Brace College Publishers.

Biber, A., (2009), "Halkla iliskiler calısmalarının dunu, Bugunu ve Gelecegine İliskin Degerlendirme",Gazi Universitesi İletisim Fakultesi Illetisim Kuram ve Arastırma Dergisi, Guz 2009, Sayı: 29 (134-148).

Blumler and Katz, (1974), “The Uses of Mass Communication: Current Perspectives on Gratification Research".

Breakenridge, D., (2008), “PR 2.0, New Media, New Tools, New Audiences”, Pearson, New Jersey, ABD.

Carey, C. (1996). "Rhetorical Means of Persuasion" and "Essay's on Aristotle's Rhetoric" (p. 405-415). US: University Of California Press.

Colak, Z., (2011) "Persuasive Strategies Used In Social Media: A Case Study On Turkcell”, "The Leading Turkish Telecommunication Company", Yeditepe Universitesi, Master Thesis.

Defren, (2009), Retrieved from http://www.shiftcomm.com/downloads/SMMarketingebook SHIFT_Communications.pdf.

D.M.Doyd, \& Ellison, N., (2007). "Social Network Sites: Definition, History, and Scholarship". Journal of Computer Mediated Communication, p. 210-230.

Emami, Hossayin, (2009), "Pratikte PR2.0", Birinci Halkla İliskiler 2.0 Uluslararası Konferansı, Kargozare Ravabet Umumi Yayinevi, Tahran, Kasım 2009, 92-105.

Guz, Hanife, Zafarmand, Nafiseh, (2009), “Sosyal Medya Baglamında Alternatif Bir Alan:Web2.0 ve PR2.0", Birinci Halkla İliskiler 2.0 Uluslar arası Konferansı, Kargozare Ravabet Umumi Yayınevi, Tahran, September 2009, 107- 119

Jowett, G. S., \& O'donnell, V., (1999). "Propaganda and Persuasion”. US: Sage Publications.

Kelly, B. ,(1997), “The Future of Digital Communication”. Mediacat Digital Age Seminar, Istanbul.

Jalali, Ali Akbar, (2009)," Halkla iliskiler 2.0", Tahran, Kargozare Ravabet Omumi Yayın Evi.

Lazaroiu, G. (2010). Social Media, Networking Software, and Creative Digital Marketing. Review of Contemporary Philosophy, 160-165.

Mayfield, Antony, (2012), "what is social media", retrieved from http://www.icrossing.co.uk/fileadmin/uploads/eBooks/What_is_Social_Media_iCrossing_ebook.pdf.

Oftadeh, Javad, (2009), “Sosyal Medya cagında, Halkla Iliskiler 2.0'ın Temeli Kullanıcıların Urettikleri İcerikler", Birinci Halkla İliskiler 2.0 Uluslar arası Konferansı, Kargozare Ravabet Umumi Yayınevi, Tahran, December 2009, 120-146. 
Paul,Marsden, (2012), "PR 2.0: How Brands are Harnessing Participatory Media in Public Relations", www.slideshare.net/paulsmarsden/pr-20-how-brands-are-harnessing-participatory-media-in publicrelationspresentation-763297, 2012.

Retrieved from www.futurworks.com, (2012).

Retrieved from http://www.alexa.com/topsites/countries/TR, (2012), “Top Sites in Turkey".

Retrieved from http://www.checkfacebook.com/2010, (2012).

Retrieved from http://www.comscore.com/, (2012).

Retrieved from http://en.wikipedia.org/wiki/media meshing, 2012, March, media meshing.

Shao, G., (2009),"Understanding the Appeal of User-Generated Media: A Uses and Gratification Perspective". Internet Research, p. 7-25.

Sherman, Aliza, (2012) "Social Media overview", retrieved from http://www.slideshare.net/alizasherman/social-media-overview-550860.

Shields, C., (2007). “Aristotle". New York: Routledge.

Solis Braian, (2009), "the Essential Guide to Social media", retrieved from http://www.onecaribbean.org/content/files/essentialGuidetoSocialMedia.pdf, September.

Solis, Braian ve Breakenridge, Deirdre, (2009), "Putting the Public Back in Public Relations, New Jersey, FT Press.

Thompson, D., (1997), An introduction to the digital media. Journalism \& Mass Communication Educator, 79-80.

Toprak, T, Yildirim, A, Aygul E, Binark, M, Borekci S, comu, T., (2009), “Toplumsal Paylasım Ag1 Facebook: Goruluyorum oyleyse Varım!" Istanbul: Kalkedon.

Turner, Jamie, Shah Reshma, (2010), “How To Make Money To Social Media”, New Jersey: FT Press

Varnelis, K., (2008), “Networked Publics”, Cambridge, MA, USA: MIT Press.

Zafarman, N., (2010), “Halkla İliskiler Alanında Yeni Mecra Ve Uygulamaların Yeri Ve Önemi: Sosyal Medya Ve Pr2.0", Gazi Universitesi Sosyal Bilimler Enstitüsü, Yayınlanmamış Yüksek Lisans Tezi, Ankara, 2010. 